\title{
Determinants Affecting Productivity of Oil Palm in Desa Air Hitam, Pondok Suguh Sub-district, Mukomuko District. Bengkulu
}

\author{
Satria Putra Utama ${ }^{1}$, Hengki Gunaman ${ }^{2}$, Agus Purwoko ${ }^{3}$ \\ ${ }^{1,2,3}$ Department of Agricultural Socio-economics, Faculty of Agriculture, University of Bengkulu, Jalan W.R. \\ Supratman Kandang Limun, Telp 62 (0736) 21170. Bengkulu City, 38371, Indonesia \\ ${ }^{1}$ Corresponding author.E-mail:satria_pu@yahoo.com
}

\begin{abstract}
The purpose of this study was to determine the factors affecting productivity in oil palm farming. The study was conducted in Desa Air Hitam, Pondok Suguh District, Mukomuko Regency, Indonesia. Desa Air Hitam in Pondok Suguh District has an area of 10,165 ha (9.87\%) of the total area of oil palm plantations in Mukomuko District. In order to increase the productivity of oil palm farming, the use of large production factors results in increased costs incurred by farmers and can have an impact on reducing the benefits they will receive. Productivity and increased use of production inputs can be detected by knowing which factors significantly influence the increase in palm oil production. The determination of the location of this research was carried out intentionally (purposive), because this area was once a transmigration settlement and has now turned into the majority of oil palm plantations. Respondents were oil palm farmers who own land from a population of 304 people, respondents were set at $20 \%$ of the total farmer population. 61 respondents were selected with the assumption that their conditions were almost the same. Primary data were collected using a questionnaire that contained all the variables measured in the study. Secondary data collected from; reports, and research results of several agencies related to this study. In analyzing the factors of production of oil palm farming, the Multiple Regression Analysis was used. The result of the study indicates, factor affecting oil palm productivity was land area, which has a very significant effect on the productivity of oil palm farming in Desa Air Hitam.
\end{abstract}

Keywords: GRDP, oil palm, productivity, multiple regression analysis, land area

\section{INTRODUCTION}

In the context of reducing unemployment in rural areas, it is necessary to develop economic sectors that absorb more labor in accordance with the characteristics/background of the rural workforce. Oil palm plantations are an economic sector with labor intensive technology. It is not only labor intensive but also accommodating to the diversity of quality/skills of rural labo [1].

Economically, oil palm plantations are developing in 190 districts and 23 provinces in Indonesia, driving the growth and development of these areas. Expansion of opportunities for work and business, increased production of goods and services, increased economic growth enjoyed by oil palm plantation centers [1].

One of the 23 provinces in Indonesia, Bengkulu Province has a total oil palm plantation of 203,082 hectares spread across several districts, with a total production of 600,372 tonnes. Muko-muko district has an oil palm plantation area of 100,061 hectares or $49.27 \%$ of the oil palm plantation area in Bengkulu Province [2].

In 2019, the most cultivated plantation commodity in Mukomuko Regency was oil palm with an area of 102,822 hectares or $89.80 \%$ of the total plantation area, followed by rubber plants with a planted area of 10,146 hectares or $8.86 \%$, while the rest was coconut, coffee, pepper and cocoa, the percentage is only $1.34 \%$ [3].

The land for oil palm plantations in Mukomuko Regency consists of the ownership of several private companies and some of them are plantations owned by the community. Smallholder oil palm plantations in Air Hitam village, Pondok Suguh sub-district, Mukomuko Regency are plantations managed independently by the local community. The owner of the oil palm plantation in Air Hitam village starts from the farming process to the marketing process of selling fresh fruit bunches to local collectors. However, in cultivating oil palm, not all farmers pay attention and carry out detailed calculations on the use of production inputs used. Furthermore, the variety of production received by 
farmers from one another is also very diverse in the range between real production and potential production that they should be able to achieve.

Various studies have also proven the importance of knowing the use of production inputs to increase palm oil production, for example, research [4], in Nigeria and [5] in Nigeria; and [6] in Brazil. In Indonesia, in an effort to increase the production of smallholder palm oil, it also has an important role in developing national plantations and creating job opportunities. Research [7] concluded that the productivity of smallholder oil palm plantations in Lampung is likely to increase along with the increasing age of the plants and the increasing use of organic fertilizers for Productive Plants and NPK fertilizers for Immature Plants. The following is the research [8] which states that there is still a significant opportunity to increase production; especially attention to several production input variables, namely land area, number of trees, and urea fertilizer. Meanwhile, the research [9] concluded that internal factors (work motivation) and external factors (opportunity for achievement) have a significant effect on the productivity of oil palm harvesters. This is because the harvest of fresh fruit bunches is determined by how productive the harvester's workforce is. The question that arises is how to determine the production input that will greatly influence the increase in specific location palm oil production? Therefore, a study that aims to determine the factors or input production that is appropriate for oil palm farmers is needed.

For this reason, it is necessary to conduct research on "Use of Inputs Affecting Palm Oil Productivity in Air Hitam Village, Bengkulu", so that farmers get a picture of the correct, precise, and efficient use of production inputs in farming.

The purpose of this study is to examine what production factors significantly influence smallholder oil palm production by presenting a multiple regression analysis of the input use by local farmers.

\section{MATERIALS AND METHOD}

\subsection{Determination of Research Location}

Bengkulu Province consists of nine districts and one city, wherein five districts and one city are located on the Bengkulu Coastline. The research was carried out on oil palm farmers in Air Hitam Village, Pondok Suguh Sub-District, Mukomuko Regency, Bengkulu Province. This district was chosen as the research location because it is one of the largest oil palm producing areas in Bengkulu Province.

\subsection{Population and Sample}

The population in this study were all 304 oil palm farmers in Air Hitam Village, Pondok Suguh Sub-District, Mukomuko District. Respondents were taken as many as $20 \%$, namely 61 people. The sample was taken by using simple random sampling method. Field data and information were obtained using a questionnaire by conducting direct interviews with respondent farmers.

\subsection{Data Analysis Methods}

1. Data Collection Method.

Primary data were collected using a questionnaire obtained from respondent as many as 61 oil palm farmers in Air Hitam Village, Mukomuko District: and secondary data were collected from the local Agriculture/Plantation Office, the Central Statistics Agency and other relevant agencies.

\section{Research Variables}

This study has 2 (two) groups of variables, namely: the independent variable group, such as; production inputs (land, age of oil palm plants, fertilizers, pesticides, and labor); and the dependent variable, such as; oil palm production.

The indicators for each variable were as follows:

a. Characteristics of oil palm farmers, namely: age, education, number of family members, experience in oil palm farming;

b. Production inputs, consisting of: land area, oil palm seeds, PHONSKA and Urea fertilizer, pesticides, number of workers;

c. Production, namely: palm oil production.

3. Data Analysis Methods, including:

a. Descriptive Analysis, consisting of: percentages and averages used to explain the socio-economic profile, type of farming, oil palm cultivation technology practices, production and use of inputs by oil palm farmers in Air Hitam Village, respondent education, farming experience, and age of oil palm trees.

b. Multiple Regression Analysis, is used to determine the factors that affect the production achieved by farmers.

\section{RESULTS AND DISCUSSION}

\subsection{Respondents' Profile}

\subsubsection{Socio-demographic Characteristics}

The socio-demographic characteristics of the respondent oil palm farmers interviewed are presented in Table 1.

Farmers' ages ranged from 25 to 68 years with an average of 44.44 years. The results of research [10] concluded that age was an important factor affecting oil palm productivity. For educational attainment, the average was over 8.23 years of formal schooling. In contrast to age, education did not have a significant effect on the productivity of permanent labor [11]; In terms of farming experience, the average was 12.28 years. The average number of household members is 3 . 
Table 1. Socio-demographic Characteristics of Oil Palm Farmers

\begin{tabular}{|c|l|r|r|c|}
\hline No & \multicolumn{2}{|c|}{ Characteristics } & Average & Persentage \\
\hline 1 & Age (year) & $25-39$ & & 31.45 \\
\hline & & $40-54$ & 44.44 & 50.82 \\
\hline & & $55-68$ & & 18.03 \\
\hline 2 & Length of Education (year) & $1-6$ & & 50.82 \\
\hline & & $7-12$ & 8.23 & 32.79 \\
\hline & & $12-16$ & & 16.39 \\
\hline 3 & Number of Household Members (person) & $1-3$ & & 68.85 \\
\hline & & $4-6$ & 3.00 & 31.15 \\
\hline 4 & Farming Experience (year) & $2-9$ & & 34.43 \\
\hline & & $10-18$ & 12.28 & 47.54 \\
\hline & & $19-26$ & & 18.03 \\
\hline
\end{tabular}

Source: Primary Data, 2019

\subsection{Physical Factor}

The average distance of respondents' homes to the location of their farm $(0,918 \mathrm{~km})$ was not significantly different among respondents, this is because the farm that the cultivated was once a transmigration settlement and has now turned into the majority of oil palm plantations. The results of the study [12] stated that distance from the home of respondents to their farm area was not an important factor influencing oil palm production. The respondent farmers were farmers who own their own land, and their main occupation is oil palm farming. (Table 2).

Table 2. Distance from the home of respondents to their farm area

\begin{tabular}{|l|r|r|c|}
\hline \multicolumn{2}{|c|}{ Item } & Average & Persentage \\
\hline \multirow{2}{*}{ Distance from home $(\mathrm{km})$} & $<0.50$ & \multirow{2}{*}{0.918} & 4.92 \\
\cline { 2 - 3 } & $1.00-2.00$ & & 95.08 \\
\hline
\end{tabular}

Source: Primary Data, 2019

\subsection{Oil Palm Farming}

\subsubsection{Resource Use and Yield}

Table 3 shows that the average yield of oil palm in Air Hitam village was 2,704 kg/ha. The average area of land cultivated by farmers was 3.23 ha, and the majority of farmers cultivating oil palm using a plant population per hectare as many as 140 stems. Wherein the age of the existing oil palm plants was an average of 10.92 years. For fertilizer, the average use of PHONSKA and Urea by farmers was $473.75 \mathrm{~kg}$ and $243.45 \mathrm{~kg}$, respectively. In terms of insecticides used by the farmers were 2.869 liters per hectare. The average labor used by farmers in oil palm farming in Air Hitam Village was 16,926 mandays per hectare per month.

Table 3. Average Production and Use of Oil Palm Farming Inputs in Air Hitam Village

\begin{tabular}{|l|r|}
\hline \multicolumn{1}{|c|}{ Unit } & Rp/ha \\
\hline Production & 2,704 \\
\hline Yield (kg/ha) & \\
\hline Production input & 3.23 \\
\hline Land area (ha) & 140.00 \\
\hline Number of plants (ha) & 10.92 \\
\hline Plant Age (year) & \\
\hline Fertilizer & 473.75 \\
\hline - PHONSKA (kg) & 243.45 \\
\hline - Urea (kg) & \\
\hline Pesticide (kg/liter) & 2.869 \\
\hline - Insecticides & 16.926 \\
\hline Labor (mandays) & \\
\hline
\end{tabular}

Source: Primary Data, 2019 


\subsection{Oil Palm Production}

Figure 1 shows the highest average production was $2,992 \mathrm{~kg}$ of land area ranging from 0.50 - 3.70 ha with $62.30 \%$ farmer ownership. This was followed by a land area of 7.01-10.00 ha with the owner's distribution only $3.28 \%$ and an average production of $2,600 \mathrm{~kg}$. The smallest average was the land area ranging from $3.71-7.00$ ha with production of $2,519 \mathrm{~kg}$ with $34.42 \%$ farmer ownership. The average production of all land holdings were $2,704 \mathrm{~kg}$. However, more than half of the respondents had a land area of $0.50-3.70$ ha.

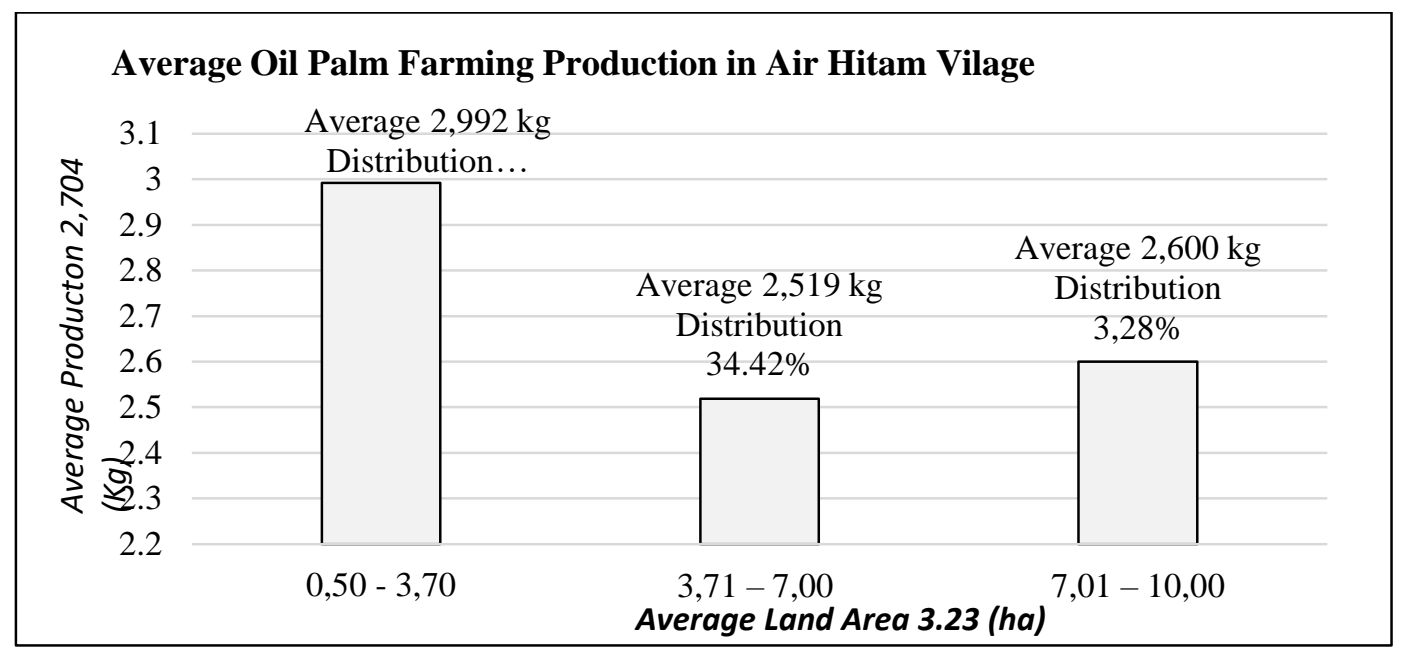

Picture 1. Average Oil Palm Farming Production Based on Land Area in Desa Air Hitam

\section{Estimation of Factors Affecting Palm Oil Production}

To identify factors that affected variation in oil palm production: land area, plant age, fertilizers (PHONSKA and Urea), Insecticide, and labor are determinant factors considered in this study.

The result of regression analysis of factors affecting oil palm production was presented in Table 4. Result of estimating OLS (Ordinary Least Square) showed that this model was statistically significant at $\alpha=$ 0.05 . This was shown with F-value being 9.63. The $\mathrm{R}^{2}$ of estimates was 0.517 , indicating that $52 \%$ of total variation in oil palm production was determined by factors included in the model. The OLS estimate showed that land area statistically influenced oil palm production. This result supports [13] research finding, stated that more efficient small farm than broad farm. Moreover, [14] concluded from the results of the study that land area and urea fertilizer had a significant effect on oil palm production in Sungai Buluh Village, Singingi Hilir District, while labor, TSP fertilizer, $\mathrm{KCl}$ fertilizer, and pesticides had no significant effect on palm oil production.

Several variables in this regression analysis indicated had a negative effect on oil palm production, such as land area, plant age, urea fertilizer, insecticides, and labor. It may be that the farmers did not have sufficient knowledge and skills about applying production inputs to their oil palm plantations properly. Some of these factors such as plant age, fertilizers (urea), insecticides, and labor have no significant effect on oil palm production. In contrast to the research of [15], there was a significant influence between oil palm production in Indragiri Hilir, namely fertilizer, labor, plant age, herbicides, and artificial soil typology.

Table 4. Estimation Results of Factors Affecting Palm Oil Production

\begin{tabular}{|l|r|r|r|r|}
\hline \multicolumn{1}{|c|}{ Independent Variable } & Regression Coefficient & Standard Error & $\boldsymbol{t}$ Count & $\boldsymbol{p}$ \\
\hline Constanta & 8.150 & 0.498 & 16.891 & 0.000 \\
\hline X1 : Land Area (ha) & -0.133 & -0.021 & $-6.160^{*}$ & 0.000 \\
\hline X2 : Plant Age (years) & -0.008 & 0.069 & -0.114 & 0.910 \\
\hline X3 : PHONSKA (kg) & 0.143 & 0.135 & 1.091 & 0.280 \\
\hline X4 : Urea Fertilizer (kg) & -0.090 & 0.184 & -0.501 & 0.618 \\
\hline $\begin{array}{c}\text { X5 : Pestisida (liter) } \\
\text { - Insecticedes }\end{array}$ & -0.117 & 0.068 & -1.709 & 0.093 \\
\hline X6 : Labor (mandays) & -0.047 & 0.043 & -1.119 & 0.268 \\
\hline
\end{tabular}

Source: Primary Data, 2019

* Significant effect at a significant level $95 \%$

Notes: $\mathrm{R}^{2}=0,517, \mathrm{~F}$ count $=9,63, \mathrm{~F}$ table $=2,15, t$ table $=1,9$ 


\section{CONCLUSION}

The research can be concluded that: (1). The average production that can be achieved by oil palm farmers in Air Hitam village is currently 2,704 tonnes per hectare per month. (2.) The production factor that influences smallholder palm oil production is 'land area'. Suggestions; Limited land ownership by farming oil farm communities is an obstacle and also a challenge in efforts to increase the production of fresh fruit bunches. Intensification is one effort that can be carried out, such as increasing farmers' knowledge through non-formal training (extension and training) regarding the efficiency of using production inputs.

\section{ACKNOWLEDGMENT}

Thanks are addressed not only to the Head of Air Hitam Village but also to all Air Hitam Village respondents who have been willing to spend time, cooperate, and provide all the information needed in completing field data and research work.

\section{REFERENCES}

[1] PASPI, Kebun Sawit Tidak Sesuai Untuk Tenaga Kerja Desa. In Mitos Dan Fakta Perkebunan Kelapa Sawit Dalam Isu Sosial, Dan Pembangunan Pedesaan, 3rd ed. Bogor, 2017.

[2] Badan Pusat Statistik Provinsi Bengkulu, Pertanian, Kehutanan, Peternakan, Dan Perikanan. Provinsi Bengkulu Dalam Angka 2019. Provinsi Bengkulu. Bengkulu, 2019.

[3] Badan Pusat Statistik Kabupaten Mukomuko, Pertanian. Kabupaten Mukomuko Dalam Angka 2019. Kabupaten Mukomuko. Bengkulu, 2019.

[4] E. Obong, O. Ibok, E. Udoh, and E. Daniel, "Insights on Oil Palm Production Variation and Trade Growths Rates in Nigeria," Greener J. Agric. Sci., vol. 3, no. 7, pp. 536541, 2013.

[5] S. Binuomate and A. Adeyemo, "Determinants of Palm Oil Production in Nigeria," Greener J. Agric. Sci., vol. 5, no. 4, pp. 110-117, 2015.

[6] I. P. Klemann, I. M. Leal, C. Faris, and R. Das, "The Evaluation Of The Determinants Factors For The Increase Of The Production In An Oil Palm Company," J. Eng. Exact Sci. - jCEC, vol. 6, no. 3, 2020, doi: 10.18540/jcecvl6iss3pp0320-0325.
[7] B. Hafif, R. Ernawati, and Y. Pujiarti, "Opportunities for Increasing the Productivity of Smallholders Oil Palm In Lampung Province," J. Littri, vol. 20, no. 2, pp. 100-108, 2014.

[8] N. Saidin, D. M. Napitupulu, and M. Saad, "Analysis Of Technical Efficiency, Source Of Inefficiency And Risk Preferences Of Farmers And Its Implications In The Efforts To Improveproductivity Of Palm Oil Plantation In Jambi Province Of Indonesia," RJOAS, vol. 11, no. 95, p. 83, 2019, doi: DOI 10.18551/rjoas.2019-11.11.

[9] T. Tennisya, T. Noor, and Setiawan, "FaktorFaktor Yang Mempengaruhi Produktivitas Tenaga Kerja Pemanen Kelapa Sawit Di Pt. Perkebunan Nusantara Iii (Persero) Medan," J. Agricore, vol. 4, no. 1, 2019.

[10] Sriyoto, A. Irawan, and Kianditara, "Analisis Faktor-Faktor Yang Mempengaruhi Produktivitas Pemanen Kelapa Sawit (Kasus Pada PT Socfin Indonesia Perkebunan Aek Loba Kecamatan Aek Kawasan Dan Kecamatan Pulau Rakyat Kabupaten Asahan Provinsi Sumatera Utara)," AGRISEP, vol. 7, no. 2, pp. 85-96, 2008.

[11]D. Setiawati, Fikriman, and Isyaturriyadhah, "Faktor - Faktor Yang Mempengaruhi Produktivitas Tenaga Kerja Panen Kelapa Sawit Di Pt. Perkebunan Nusantara Vi Unit Usaha Rimbo Satu (RIMSA)," Cemara, vol. 16, no. 1, 2019.

[12] S. Bindrianes, N. Kemala, and R. G. Busyra, "Produktivitas Tenaga Kerja Panen Kelapa Sawit dan Faktor-Faktor Yang Mempengaruhinya Pada Unit Usaha Batanghari di PTPN VI Jambi," Agrica (Jurnal Agribisnis Sumatera Utara), vol. 10, no. 1, pp. 74-85, 2017.

[13] Soekartawi, Analisa Usahatani. Jakarta: UI Press, 1984.

[14] E. Panjaitan, U. Paman, and Darus, “Analisis Pengaruh Faktor Produksi Terhadap Produktivitas Usahatani Kelapa Sawit Pola Swadaya Di Desa Sungai Buluh Kecamatan Kuantan Singingi Hilir, Kabupaten Kuantan Singingi," J. Din. Pertan., vol. 36, no. 1, pp. 61-68, 2019.

[15] Heriyanto, Karya, Choanji, Asrol, Bakce, and Elinur, "Regression Model in Transitional Geological Environment For Calculation Farming and Production of Oil Palm Dominant Factor in Indragiri Hilir Riau Province," J. Geosci. Eng. Environ. Technol., vol. 4, no. 1, 2019. 